\title{
Parallels and contrasts - Wendezeit in South African and German literature
}

\author{
Peter Hom \\ Department of German \\ University of Cape Town \\ CAPE TOWN
}

\begin{abstract}
Parallels and contrasts - Wendezeit in South African and German literature

We live in the present, but our language is always the language of the past. Memory is fragile, evanescent and often distorted. Even where memories are vivid and subjectively compelling, there is no guarantee that they are correct. The documents which come down to us are riddled with lacunae, silences, and with outright lies. But these documents are the basis and the limit of our constant rewriting of history. Official history is an erasure of an alternative history. The truth, which surfaces in myths and stories, is the truth forgotten by history, or more precisely, the truth repressed by history. Not only the henchmen and the prison warders have a bad memory. The victims, too, have difficulties remembering. But not to want to know the truth about oneself is an attitude which always leads to catastrophe. Literature discovers the dark underworld beneath the glittering surface of this country, which considers itself to be happy. It is art, the novel, the poem, the image, which transcends the boundary of that area which is excluded from langwage. Fictional reports can, however, do that only because they lack the authority of official history writing, because that which is wrilten fictionally has been called a lie since the time of Plato. There is, nevertheless, a silence underneath the rationality of the historical method, an unknown.
\end{abstract}

\section{The truth repressed by history}

"Dead Gods, too, are governing" (Wolf, 1996:13). This is the opening sentence of Christa Wolf's novel Medea. We live in the present, but our language is always the language of the past. That is true in Germany, where the past goes deep, much deeper than those "zero" years at the end of World War II and at the end of the GDR, years where for most memory ceases. That is true for South Africa, where the destruction of the indigenous population did not start in the year 1948, when the social engineers of apartheid came to power. Here too, there is a much greater depth of written history, and beyond written history a much greater depth of prehistory, transmitted to us through fables, rock paintings, 
archaeological finds and songs. Somewhere in the darkness of several million years we sense those beginnings when the Australopithecus bashed in each other's respectable skulls.

The truth, which surfaces in myths and stories, is the truth forgotten by history, or more precisely, the truth repressed by history - because were it only forgotten, it would not penetrate our language, our fantasy, our wishes, our dreams and our actions with such force. If the truth were forgotten, we would be rid of it. Instead we labour under the heavy load of history which constantly repeats itself, symptom of an unresolved past: "Sooner or later we are all overtaken by our own stories", says André Brink (Jolly, 1996:249).

But in his book, On the Contrary (Brink, 1993), there is another way of telling stories in the mythical past: "In the beginning there was only [...] a Storyteller and she was a woman." The black slave woman whose proper name has been lost under the superimposed European name has her own stories, stories which create the land and the paths across the land, stories which create the order in which people can live, but stories, of course, are not histories and her stories are not taken seriously because she is black, a woman and a slave, thus a loser of history. History is made by the winners. It is they who determine what goes into the documents, it is their voice which assumes the authority to tell it how it is, and who therefore authorise and circumscribe the order which determines the choices we can make in our lives. Thus it happens that according to this myth by André Brink, she is forgotten by the very things and beings which she had created as a story, and the "forgotten Storyteller fell asleep into a deep sleep of ages, because they no longer seemed to need her" (Brink, 1993:184).

The documents which come down to us are riddled with lacunae, silences, and with outright lies. But these documents are the basis and the limit of our constant rewriting of history. Women, slaves, rebels, revolutionaries are not represented in these documents in their own writing, but always only in the writing of their masters.

\section{Certain victors are treating history like that}

If one has experienced the 8th of May 1945 in Germany, the 12th of February 1990 in South Africa and the 3rd of October 1990 in Germany, one knows that such dates are not only a fissure in time, a fissure which separates today from yesterday decisively, but also a fissure in one's own biography; I find it more and more difficult to remember myself as the one who lived before 1990, not to talk about myself as the one who lived before 1945. The East German writer Christa Wolf has investigated such fissures in her own biography in her novel Kindheitsmuster. The belief, however, that such historical events are not only a 
fissure but a point zero, testifies to a tendency towards amnesia or towards the development of a selective memory. This is something which can be observed in both states. The articles of certain journalists, "who celebrated the 3rd of October as the climax of the 'success story of the Federal Republic of Germany' - and as the final victory over socialism and the 'intellectual left"' (Anz, 1991:165) has its inverse correspondence amongst those whites in South Africa, who have suddenly become citizens of the 'new' South Africa, but who want to know nothing of either the misdeeds of the apartheid-regime or the struggle of its opponents. "Certain victors are treating history like that" (Wolf in Anz, 1991: 105). But certain losers, too. Whatever was in the past shall be destroyed: a white South African editor wrote to me last year: "I also think that South Africans are tired of reading about the 'struggle' and want to move on - or at least feel as if they are moving."

It is, of course, whites, who were never very interested in the struggle against apartheid, who think like that. Similarly certain German intellectuals now know that "the other Germany was from its very origin and in all details null and void" (Anz, 1991:105). Thomas Anz has formulated that as follows in his book about the literary polemics surrounding Christa Wolf: “... with the collapse of the party dictatorships in Europe, calling themselves socialist or communist, leftintellectual criticism in the Federal Republic is supposed to have lost its credibility" (Anz, 1991:18). Anz depicts the triumph of those who never liked this trend anyway: "Finally one believed to have the intellectuals in East and West simultaneously in a spot, where one could find them guilty of a dangerous utopism and as the true enemies of the people" (Anz, 1991:19).

But it is not that easy to lay the ghosts of the past to rest, and poets and writers seem to know that better than the media, who stage the pleasure and the terror of the thirty second present. Some of these are very old ghosts, like Adamastor, first cited by Camoes in his Luciad, that frightening Titan chained to the Cape of Good Hope, who threatened the foreigners entering his realm with a disastrous future. Andre Brink has also written another novel on the theme: The First Life of Adamastor (1993b). The stories of the colonisers from the Argonauts to the rape of Vietnam resemble each other: The Portuguese, too, went forth like the Argonaut to the farthest Eastern rim of their world to find their Golden Fleece. They too thought they were involved in an adventure, they too thought of fame like Jason, they too burdened themselves with guilt. Like the Corinthians the modern European colonisers remember "that they took this piece of land from their original inhabitants whom they despised with brutal force" (Wolf, 1996:86). This story has not yet come to an end, even if Africa is said to be de-colonised today. 
In his novel On the Contrary Andre Brink (1993a) shows not only how official history is a production, but also an erasure of an alternative history. The voice of his (we would say extreme rightwing) rebel Estienne Barbier tries to portray the truth of events as he sees them. But his densely scribbled pages are torn out of the book and burned, and Menzel, who is more acceptable to the colonial regime, replaces each of his pages with another one which now lays down "the correct and proper truth" (Brink, 1993a:40), as the authorities want it to be inscribed into the records of their time and the future. All attempts to rewrite history come up against this fact - that documents of an alternative view are missing most of the time because they were prevented as they came into being or they were destroyed later on. One needs to think merely of the shredding machines, which were busy in 1945 and 1990, tearing material which was considered too sensitive by the old regime to be handed on to the new.

Because of such experiences one can perhaps understand the slightly neurotic Alfred Dorn in Martin Walser's novel Die Verteidigung der Kindheit (1991), who sees his life disappear in the shredders of the time and who could therefore never get enough mementoes of the past (Walser, 1991:14): "As soon as he noticed that something in the past wanted to slide into uncertainty or into the forgotten, he became fidgety" (Walser, 1991:17).

History can be rewritten and corrected only within very narrowly circumscribed limits, because the historian has to write a narrative based on "authentic documents" and has to exclude accounts of how it could have been. Only fiction can enter that space of the possible which is negated and silenced by the documents which claim to represent the real. Fiction is not about how it really was: fiction is an attempt to keep the story about the past open, an attempt to deny the impression the historians try to create that what they say is all there is to say about the past. Fiction deals with the possibilities which are excluded from the official documents.

But history, even if it calls itself "objective" or a science (Geschichtswissenschaft), cannot describe "how it really was". It too, deals with the documents of the past according to well defined methodologies, which determine what can be said and what cannot be said. After the ritual murder of her brother Wolf's Medea says "that we cannot deal with the fragments of the past according to our own fancy, that we cannot put them together or tear them apart as we like" (Wolf, 1996:103). It is, however, always an open or unseen ideology which produces the framework which determines how the pieces of the past are put together in a coherent narrative.

On the other hand one feels relieved of a constraint when one no longer has to bear the responsibility for official truths, where the "test for the recording of any 
observation in my official journal was the sanction of our leader; was what was judged acceptable to ulterior readers at the Cape and possibly Batavia and Amsterdam" (Brink, 1993:26). Not everyone who was the official scribe of the system or the chronicler of dissidence and resistance, has understood the end of this task as a liberation. Brink's narrator Barbier, however, says: "I was free at last to pursue my own, and in my own way" (Brink, 1993:41). But this freedom has a curious unreality; in a sense he is not writing his story and his defence, but he is being written, he is not observing but being observed (Brink, 1993:183), "inscribed as it were by another pen into [his] journey" (Brink, 1993:349). It is not only because he is sentenced to death and his body is about to be torn apart "Round to a cross, the verdict said, his right hand and his head severed from his body, subsequently to be drawn and quartered, the head and hand to be placed on a stake in the Roodezands Kloof and the four remaining quarters to be displayed in four different places alongside the most frequented highways of the Settlement as prey to the air and the birds from heaven" (Brink, 1993:3) - that he says: "I am absent from myself. I am absence" (Brink, 1993:4). The narrator is always absent in the narration.

\section{A view into the innermost chamber of horrors}

The liberation of the burden to be the chronicler of a frightening story does not mean, however, to be free of the task to describe what happened in the cellars of society. Sometimes one has to take one's distance, and has to allow one's readers to distance themselves, so that one can deal with the unbearable at all. John Coetzee writes a novel which apparently has nothing to do with South Africa, but which nevertheless allows a view into the innermost chamber of horrors: The Master of Petersburg (1994). Hiding behind the mask of a dead poet, behind the "deep, criminal countenance of a saint" (Mann, 1960:656), who mourns the death of his son, is an undertaking fraught with difficulties, difficulties for the author and difficulties for the reader and critic. That has, in the case of Coetzee, its autobiographical background, but that is not what I am interested in here. What interests me is that a poet does not join the cheering of the rainbow nation, and that he does not write that it is all over now: apartheid and oppression.

Christa Wolf writes a novel, which apparently has nothing to do with the end of the GDR - this novel is called Medea (1996) and takes place in ancient Corinthos. But this, too, is a text which is very close to the chamber of horrors. It would be wrong to read these texts merely as the palimpsest of today's Germany or of today's South Africa: such simplifying equations rob us of the distancing, which allows understanding. Nevertheless, these equations are about South Africa and Germany, the Federal Republic and the German Democratic Republic. 
Wherever there is a past, there is guilt. Christa Wolf's Medea, a "fugitive in King Kreon's gleaming town Corinthos", at first believes that this town at least has no secrets, no dark past. The Corinthians themselves attempt to create this impression. But the illusion that this is a place where people can be happy is a deception. Corinthos, too, like her home Kolchis, "was full of dark secrets" (Wolf, 1996:16). Medea had left Kolchis, because her brother had been murdered and torn to pieces by her own father for dynastic reasons (Wolf, 1996:62).

She had thrown the bones of her brother to the Kolchians who were pursuing her. But at least one had a bad conscience in Kolchis, when one dug up the old barbarian rituals again, in order to make political gains; in Corinthos one does not even have a bad conscience. "This king has no remorse, when he builds his power on a sacrilege, he looks everyone in the face boldly" (Wolf, 1996:104f).

The Corinthians have repressed the memory of the sacrilegious murder and believe in their own future happiness, but "nothing deceives more certainly than happiness" (Wolf, 1996:20). What is at stake is not the fact that the rulers of yesterday all lie, and how many people are prepared to believe these lies: "Human beings take things gently, if they can at all arrange it that way" (Wolf, 1996:132). It is not only about the fact that most people can persuade themselves that they have nothing to do with the horrors of the past. The court astrologer Akamas in Wolf's Medea says: "She must have noticed that the well-being of my dear Corinthians is directly dependent on the fact that they can believe that they are the most innocent people under the sun" (Wolf, 1996:129). The astrological minister of propaganda and manipulator of popular media, Akamas, despises those he manipulates: "I learned a lot from this case. I learned that there is no lie blatant enough, but people would still believe it, if it coincides with their secret wish to believe it" (Wolf, 1996:132).

Medea finally comes to understand: "It is like this: either I am mad, or their town is based on a crime" (Wolf, 1996:15). And when she discovers the crime, she understands: "Whoever betrays this secret, is lost" (Wolf, 1996:24). While she is accused of having murdered her brother (Wolf, 1996:44), an accusation which is based on the slimmest of fabricated evidence, Medea not only discovers the brutal murder of the king's daughter Iphinoe, she also finds the incontrovertible evidence (Wolf, 1996:15). She discovers the dark underworld underneath the glittering surface of this country that considers itself to be happy: "the king's wonderful light palace has its own counter-image built into the depth of darkness" (Wolf, 1996:21). This foundation of power is, however, concealed from the eyes of most. 


\section{The urgent wish to have been happy}

Not only the victims, their relatives and the witnesses of violence are traumatised by violence, and in their consciousness or in their unconscious there remains "an unbearable memory, which I ought to have forgotten so as to be able to live, and that was quite in order, if the forgetting had not grown with the child in the head of the child as it grew older, a dark patch which became larger" (Wolf, 1996:148). The court astrologer Akamas, who knows about all the secrets of the court, "lives in carefully constructed buildings of ideas, which he confuses with reality, which however have no other purpose than to support his easily wavering concept of self' (Wolf, 1996:84). This ego has the "urgent wish to have been happy" (Wolf, 1979:208). Medea, too, experiences the aversion against the need to uncover the inhumanity again and again: "Something in me refuses to climb down again into these caves, the underworld, into Hades, where there is dying and rebirth from time immemorial, where out of the humus of the dead life is baked" (Wolf, 1996:19). But not to want to know the truth about oneself is an attitude which always leads to a catastrophe. "Not to want to know the truth about oneself is the contemporary form of sin", says the Pole Brandys in Wolf's Kindheitsmuster (Wolf, 1979:262f). This Not-Wanting-to-Know, however, is easy to produce, as the East German dissident writer Jürgen Fuchs has shown:

In order to maintain our not-knowing about a fact or an event and its background, we do not need to set into motion a mechanism of repression. It is quite sufficient that we have no express interest, to notice something, for example, because it has no relation to us or because such a knowledge could bring obligations, which we can evade thanks to our effortlessly maintained ignorance with a good conscience (Fuchs, 1990:61).

Not only the henchmen and the prison warders have a bad memory. The victims, too, have difficulties remembering. South Africa is involved in a process of remembering in the Truth and Reconciliation Commission. That is correct and necessary, but we may not forget Medea's real insight: "We can pacify each other but we cannot repair the damage" (Wolf, 1996:32). In John Coetzee's novel it is the main character's son, Pavel, who calls himself the "orphan" (Coetzee, 1994:64), ${ }^{1}$ who was murdered or committed suicide, who above all occupies the mind of the writer, who desperately hopes: "Poetry might bring back his son" (Coetzee, 1994:17), because that "Pavel is above all lonely, and in his loneliness needs to be sung to and comforted, to be reassured that he will not be abandoned at the bottom of the waters" (Coetzee, 1994:111). What we are

$1 \quad$ Pyotr Stepanowitch Verhovensky (Dostoevsky's Nechaev figure) complains in a similar way about his father: "You gave me neither food nor drink and sent me [as a tiny baby] by post [from Berlin to X province]" (Dostocvsky, 1931:198). 
talking about is necromancy rather than the writing of history, the art of raising the dead, the art of casting a spell over a willing audience, the old poetic art of Orpheus. That at least may be within the powers of art.

But in his novel written in jail Breyten Breytenbach says:

The writer just as the reader (because the reader is the mirror to the writer) can seemingly make nothing undone. He cannot reopen the earth, cannot set the snapped neck, cannot stuff the spirit back into the flesh and the light of life in the lustreless eyes full of sand, cannot straighten the mother's back, cannot raise the assassinated, cannot reduce the man to a seed in the woman's loins while a hot wind streams over the Coast (Breytenbach, 1984a:62f.).

Memory is fragile, evanescent and often distorted. Even where memories are vivid and subjectively compelling, there is no guarantee that they are correct. The testimonies of holocaust survivors are a good example and the testimonies before the Truth Commission, too. Even the victims have moved into a state, where the memories of the holocaust or the horrors of apartheid are like memories of another life, another person, something which does not touch them any longer, something that is far distant from their current self (Nuttall, 1996:5).

No Truth Commission will ever be able to lay bare this unconscious and make it conscious. The truth will be that truth that we can bear - not the one which is unbearable to the oppressors and their rebellious victims. It is art, the novel, the poem, the image, which transcends the boundary of that area which is excluded from language. But fictional reports can do that only because they lack the authority of official history writing, because that which is written fictionally is being called a lie since the time of Plato. There is nevertheless a silence underneath the rationality of the historical method, an unknown. Medea knows about her fellow citizens: "Not all of them would always know what they knew". And in her novel Kindheitsmuster Christa Wolf asks: "Do we need protection from the abyss of memory?" (Wolf, 1979:99).

The report on the past is always full of lacunae and the lacunae prevent us from establishing that continuity of knowledge which we would need to change our life. Hegel differentiates between memory and remembrance. Remembrance subjects itself to the demands of consciousness, memory transports into consciousness those events and facts against which consciousness creates boundaries. That which we do not know consciously is that part of history which is marked by an absence or occupied by a lie. The truth which surfaces in myths and stories is that which is silenced in history. 


\section{The word "possible" excludes all the possibilities which have been judged "impossible"}

Politics is said to be the game of the possible. This innocent statement is at the root of the falsification of the record of the past and therefore the distortion of the possibilities of the future. The word "possible" excludes all the possibilities which according to the (falsified) record of the past have been judged "impossible": today this includes such "impossibilities" as anarchism and socialism. A truly human world without power, anarchic and free, "a place where life can be once more possible", therefore has become the "impossible". Andre Brink's Estienne Barbier has an inner voice that he calls Jeanne d'Arc. This inner voice and companion says:

This is the sin of all of them, all these men who turn to politics as a game to be played, a game of the possible. They become powerful because they fetter the imagination. That is the very source of their power. They forbid us to remember what is truly impossible. And by concentrating only on the possible, 1 tell you, they have made the world an impossible place to live in (Brink, 1993a:182).

Of course it does not help to create illusions, to recount the lost past as a kind of paradise. The nostalgia for the GDR, the nostalgia of some for the old South Africa, but also the dream of an innocent precolonial Africa, which never existed, are all understandable but socially dangerous, because they tend to inform social action in the wrong way or replace it by moumful non-action. It is always painful to recognise that there is no place and no time when utopia was real: "Where should I go. Is there a world, a time, into which I would fit" (Wolf, 1996:236). Medea reflects on this temptation to project happiness into the past:

We in Kolchis were animated by our ancient legends, in which our country was reigned by just queens and kings, populated by people who lived together in harmony and where property was so evenly divided that none envied the other or attempted to steal his possessions or even kill him (Wolf, 1996:99).

The danger is that "we allow a wonderful Kolchis to arise in the stories which we impart to each other, a Kolchis which existed never and nowhere" (Wolf, 1996:76). The danger of course is that such nostalgia makes us unable to think something new.

Whoever listens to myths only, very easily falls into the trap of ignoring another reality. Jürgen Fuchs for example had begun to understand that "art" can be a secret cipher and a slave-language; this experience made him allergic against 
certain strategies to transfer experiences into "art". 2 He "always understood reality as the feeder of the muses" (Fuchs, 1990:12). But the distancing which art allows became suspect in a situation in which open speech became impossible: "Bobrowski's dark silences, Brecht's superiority are suddenly repugnant, alien, hate for art" (Fuchs, 1988a:157).

"This is not going to be art". This is a sentence which appears in the language conglomerate under the title "Berlin-West" at the end of the Vernehmungsprotokolle by Jürgen Fuchs (1988b:227). Well, perhaps not. What is the use of art in times like these? "Art, you may remember ...", says Paul Celan ironically in his Büchner-Prize acceptance speech. Certainly we remember that there was something like art. Those who refuse the temptations of making "art", however, are disqualified, because they seem to present reality in its raw form: "Your poems, these things, that is slander of the state" (Fuchs, 1990:33). The honorific predicate "art" is denied them. The attentiveness of the reader is defined as an ephemeral one. This is one possibility for the functionaries of the GDR, not to pay any attention to the criticism of the prisoner awaiting trial, to disparage his writing, to put it outside the bounds of literature, the limits of an accepted discourse: "Naturally that is not literature, what you write here, but filth, simply filth" (Fuchs, 1988a:160). Fuchs asks himself: "Is somebody ever going to talk publicly [about his work] as of 'stories', of 'prose', and not as of 'stuff' and "concoction'?" (Fuchs, 1988b:111).

But after 1990 nobody wants to hear this discourse anymore: no, one discredits any kind of "aesthetics of conviction", and included in this derogatory term is any literature which documents the injustices to which human beings were subjected before 1990 in South Africa or in the GDR. True, it is not an innocent act to write or to read about violence: because the reader-spectator of an atrocity always takes a privileged position, that of the voyeur who is implicated in the scene he watches because of his desire to watch. Even if we are indignant about the violence, we do not escape the relationship between torturer, tortured and voyeur. What is our desire to write or read such things, asked Schiller. And which authority does the writer usurp, when he narrates, to put his voice in the place of the voices of the tortured bodies? This is a question which is very

2 In a conversation the Polish writer Zagajewski talks about the illusory freedom of Polish literature in the last years of Communist rule: "There was a great freedom of literary experiments. That seemed suspicious to me and my friends, in a state which permitted so little, artistic form should be an exception? That was something ambiguous, nebulous. One is allowed to say so little in public, but onc is allowed to express oneself abstractly, expcrimentally in art" (Fuchs, 1984:53). In this same conversation he continues to say: "A purely aesthetic stance in a police state results from cowardice, from the wish to avoid difficulties. Now I would not say this in the same way any longer" (Fuchs, 1984:57). 
topical in South Africa at this moment, when the victims of the torturers and their next of kin tell their own stories in front of the Truth and Reconciliation Commission.

On the other hand, the writer cannot remain silent in view of the terror, because silence would be assent, too. Every white South African, even the opponents of the apartheid regime, were implicated in the colonial situation, were, however reluctantly, colonials. André Brink was criticised by many for his novel $A$ Chain of Voices (1982), for "its portrayal of the violent as intimate, and therefore in a sense desirable" (Jolly, 1996:39). That is indeed one of the most unsettling aspects of the novel - unsettling because it destroys the old "fallacy, that the political does not impinge on the private, which has been, not coincidentally, one of the long-standing myths of the apartheid regime" (Jolly, 1996:65).

\section{Why should you believe yourself?}

A key question in Coetzee's novel The Master of Petersburg is "whether it is possible to tell the truth about oneself", a question which he has investigated as a critic in his essay "Confession and Double Thoughts: Tolstoy, Rousseau, Dostoevsky" (Coetzee, 1992b:275), which however has another, existential quality in the novel. Anna Sergeyevna asks "Dostoevsky": "Do you act from the heart all the time? I don't think so" (Coetzee, 1994:167), and she spells it out even more clearly: "Why should I believe you? Why should you believe yourself?" (Coetzee, 1994:167). The second question is the more terrifying question. It does not only put a question mark behind the concept of honesty, but puts into question the possibility of truth itself, of truth as the possibility to know oneself. At the end of Dostoyevsky's encounter with him, Nechaev screams "in a voice that makes the cellar ring": "Truth? What is the truth?" (Coetzee, 1994:203).

Although Coetzee's "Dostoyevsky" reflects with astonishing openness all that he discovers in himself to be evil, ridiculous and shameful, he nevertheless shows "nothing so much as the helplessness of the confession before the desire of the self to construct its own truth" (Coetzee, 1992a:279). What we are talking about is a "confession made via a process of relentless self-unmasking which might yet be not the truth but a self-serving fiction" (Coetzee, 1992a:280). In this "politics of desire" (Coetzee, 1990:8) it can be that we tell a kind of truth about ourselves because we have "a desire to be in a particular way" (Coetzee, 1992a:280), and that we can never objectively describe this desire, without getting caught in desire itself.

So, how about the desire of the writer to tell the truth? Is that, too, not an element of writing, which leads one to the limits of the ethical? The writer is 
always a kind of spy, whether he works for the government or not: because he wants to know, and because knowledge is the basis of power, the writer constantly offends against the privacy and puts into question the very concept of the private. Coetzee's "Dostoyevsky" does understand very well that the observation of people and their behaviour, this private spying, is part of the art of writing: "As a child he used to spy on visitors to the household and trespass surreptitiously on their privacy. It is a weakness that he has associated till now with a refusal to accept limits to what he is permitted to know, with the reading of forbidden books, and thus with his vocation" (Coetzee, 1994:71). Writing necessarily transgresses the boundaries of what is permissible.

The terror is over, we are told - even if one hesitates to believe that - the trauma which was caused by this terror continues. What seems to me most problematic, however, is the insight that violence is intimately connected with that which we are told is our very desire: the nation; the insight that a "sadistic rhetoric - is a strategy we can identify as one upon which the creation of both the nation and its state depend" (Jolly, 1996:66). Perhaps we should not forget the terror and the trauma so that we are not overtaken by a new trauma.

The violent confrontation between the interrogator and the prisoner "is a situation authored by the controlling ideology of the nation state. This ideology, the foundation upon which concepts of nationalism and state 'security' rest, subsists by replicating and propagating the notions of self and other found in the relationships of dominance and submission" (Jolly, 1996:66), and this power as the origin of civilisation (according to Hegel) is always close to the racist concepts of an ethic of national unity. The state of affairs described by Peter Schneider in 1982 must disappear: "West faces stare into East faces, as if humans look at apes" (Schneider, 1982:10). It is irritating if Germans still see each other as 'Ossis' and 'Wessis', even after the re-unification; irritating, if South Africans still emphasise their belonging to different races and cultures. But sometime in future, that is the hope of the new states, the unity of the "rainbow nation" will be achieved, the one and united nation absorb all differences. On the other hand, one is not surprised, if in the new South Africa and the new Germany racist abuse and violence are spreading: anti-Semitism and white purity of race have been hiding for a long time underneath the flag of patriotism, charged with the duty to clean the fatherland from impurities. The nationalist rhetoric, which one can hear in South Africa and Germany, with hardly anybody taking offence, always identifies the state as the true self, and all those he sees as a danger to this state, as the others. One step further and we hear Reagan say that it is "not right versus left; it is right versus wrong" (Jolly, 1996:67). 


\section{The state lives inside you}

In order to uphold the nation state one needs to create a unified or re-unified subject against the others, in other words, individuals which have such a reunified consciousness. "The state lives inside you. You are its condition" (Breytenbach, 1984b:215). Or in the words of Christa Wolf: "They have remodelled each of us into the one they can use" (Wolf, 1996:57). In every nationalist discourse the depiction of the self always depends on the construction of such an other. The autonomy of such subjects remains phantasmatic. Such subjects take part in the construction and upholding of the nation state, because they have been made to believe that this state is in their own interest: "The 'selljob' of such discourse is to convince people that they are 'autonomous individuals', possessed of subjectivity or consciousness which is the source of their beliefs and actions" (Jolly, 1996:69).

What the fight against apartheid but also the resistance of the dissidents of the GDR have shown, is the reaction of the state, if the ideological machine breaks down, which is supposed to produce the individual as a unified subject. If the subjects refuse to take part in the discourse of the "self" and the "other" in the way the state defines this discourse, the state has to use its last resort, violence, in order to enforce its idea of "individuality". The state can never admit that the ideological operations which it produces in order to maintain its sovereignty can be wrong. The state therefore has to blame the individual who has been "unable" to adapt to the state's definition of subjectivity for the failure of these operations (Jolly, 1996:69).

Such an author, who refuses to conforn to the accepted discourses of East or West, is Jürgen Fuchs. Fuchs' experiences with authoritarian structures started early in his life in school. In a conversation with his erstwhile teacher, Gerhard Hieke - "Dumm geschult? Ein Schüler und sein Lehrer" - he shows, how school is already an institution for an education to conformity. Again and again he experiences: "A non-public apparatus of officials regulates the consciousness of the general public and defies any control by society" (Fuchs, 1990:73). That is true for school, university, the military, jail, the system of justice and psychiatry.

During his time in the military Fuchs begins to write about the reality of militarism in the GDR: "Notes, hints. Some of it I wrote down then ... Most of what comes out of this time is nasty, gnawing wakefulness in my head. Memory protocols which deny forgetting" (Fuchs, 1988b:137). Because of the constant controls and the complete loss of any privacy he can hardly write anything down during his time with the military. It is even worse during his time in jail. It is only in West Berlin that he can reconstruct from memory what actually happened to him. 
Fuchs turns particularly sharply against "the degradation, isolation, classification, and functionalisation of people typical for the military, institutions and jails" (Fuchs, 1984:110). He knows from his own experience that in the army "young people are turned [...] into subjects, who obey" (Fuchs, 1984:118). One of the witnesses against the war, the army and its devastations is for him the German poet "Borchert, 'We will never again fall in line obeying a whistle', this sentence has determined and changed my life, has challenged me deeply" (Fuchs, 1990:11). What he began to understand in the army was that armies are not in the first instance there to protect the state against external threats: "We were moved in the first instance by that compelling component of a standing army which is turned against its own population" (Fuchs, 1984:110).

Fuchs contests the right of the GDR to "hide behind the flags it had stolen from a murdered revolution" (Fuchs, 1990:70). He does not allow the professor who interrogates him "to appoint himself as the speaker of the working class", especially if the professor feels this to be an impertinence and screams at him not to answer back unless asked to do so (Fuchs, 1988a:81). The verbally helpless attempt of the professor to devalue all dissident opinions as a "conglomeration of all kinds of ideas which are furthermore uttered publicly to confuse the students" (Fuchs, 1988a:84), unmasks itself. "They built the new state and organised it in a Stalinist way. They were the victims [of the Nazis] and now became the culprits. And that in conjunction with their speeches: We are anti-Fascists, we are right, we sat in jail, not Filbinger and Globke" (Fuchs, 1990:31). Fuchs quotes Lenin to make his point: “... a much stronger layer of a occupationally limited, narrowminded, selfish, fossilised, self-centred, petty-bourgois, imperialist minded 'worker aristocracy' has created itself' (Fuchs, 1988b:98). Reading Lenin he found, too, evidence of a contempt of human beings, which he finds again as the fundamental layer of "real socialism": Lenin, too, unmasks himself as the layer of the foundation stone of the violence against his own, as somebody who attacks his enemies as "hysterics amongst the intelligentsia", as "harmful elements", as somebody who speaks of human beings as "vermin", which one ought "to shoot immediately" (Fuchs, 1988b:190f).

In 1982 already Peter Schneider had written in his novel Der Mauerspringer (The Wall-Jumper): "It will take longer to tear down the Wall in the head, than any demolition squad will take for the visible Wall" (Schneider, 1982:117). Literature will not cease to write about the things which happened before 1990 neither in Germany nor in South Africa. When in 1992 twelve South African writers were invited to France, we were asked what we would write about now that apartheid is over. It would have been ridiculous, were it not so sad. Certainly the world media and satellite TV have found other theatres of war. But what happened to human beings in 350 years of colonisation cannot be forgotten from one day in February to another. The consequences of these crimes will be 
felt for generations. But what will be possible are new visions of old stories; visions, which hopefully will lead us to greater understanding and to healing. Because: "Before the rejuvenation of our society has not penetrated the depth of self-questioning and self-criticism of each and everyone, it remains symptomatic, open to abuse and endangered" (Wolf in Anz, 1991:25).

Such a questioning can only be done with the seriousness of an autonomous literature and the freedom, without which the writer becomes a vicarious agent of the owner of the media or a political party or the government.

Recause of this the citizenship of the writer must remain problematic for ever, the writer remains after 1990 what he had been before, an incorrigible jumper over walls (Mauerspringer): "If my fatherland exists, it is not a state, and the state whose citizen I am, is not a fatherland. [...] If I am asked where it is, I would be able to point to no other place than its history and the language which I speak" (Schneider, 1982:124).

\section{Bibliography}

Anz, T. 1991. 'Es geht nicht um Christa Wolf'. Der Literaturstreit im vereinigten Deutschland. München : Edition Spangenberg.

Breytenbach, Breyten. 1984a. Mouroir: Mirrormotes of a Novel. London and Boston : Faber.

Breytenbach, Breyten. 1984b. The True Confessions of an Albimo Terrorist. Emmerentia : Taurus.

Brink, A. 1982. A Chain of Voices. London : Faber.

Brink, A. 1993. On the Contrary. London: Secker \& Warburg

Brink, A. 1993. The First Life of Adamastor. London : Secker and Warburg.

Coetzee, J.M. 1990. Censorship and polemic: the Solzhenitsyn affair. PREtexts, 2 (2):3-36

Coetzee, J.M. 1992a. Dowbling the Poimt. Fssays and Interviews. Edited by David Attwell.

Cambridge/Mass. \& London : Harvard University Press.

Coetzee, J.M. 1992b. Confession and Double Thoughts: Tolstoy, Rousseau, Dostoevsky.

In: Coetzee, J.M. Doubling the Point. Essays and Interviews. Cambridge/Mass. \&

London : Harvard University Press. p. 251-293.

Coetzee, J.M. 1994. The Master of Petersburg. London : Secker and Warburg.

Dostoevsky, F. 1931. The Possessed. Translated by Constance Garnett. London : William Heinemann. (First printed 1914.)

Fuchs, J. 1984. Einmischung in eigene Angelegenheiten. Gegen Krieg und verlogenen Frieden. Reinbek : Rowohlt.

Fuchs, J. 1988a. Gedächtmisproiokolle. Vernehmmmgsprotokolle. Reinbek: Rowohlt

Fuchs, J. 1988b. Das Ende einer Feigheit. Reinbek: Rowohlt.

Fuchs, J. 1990. “... und wann kommt der Hammer?" Psychologie, Opposition und Staatssicherheit. Berlin : BasisDruck.

Jolly, R.J. 1996. Colonisation, Violence, and Narration in White South African Writing. André Brink, Breyten Breytenbach, and J.M. Coetzee. Athens : Ohio University Press; Johannesburg : Witwatersrand University Press.

Mann, T. 1960. Dostojewski - mit Maßen. In: Thomas Mann. Reden und Aufsaize Gesammelte Werke in zwolf Bänden. Fischer Verlag Bd. 9:656-668 
Nuttall, S. 1996. Repression. (Review of Memory Distortion: How Minds, Brains and Societies Reconstruct the Past. Ed. by Daniel Schacter. Harvard University Press 1996.) In: Southern African Review of Books: 3-5, July/August.

Schneider, P. 1982. Der Mauerspringer. Darmstadt und Neuwied : Luchterhand.

Walser, M. 1991. Die Verteidigung der Kindheit. Frankfurt am Main : Suhrkamp.

Wolf, C. 1979. Kindheitsmuster. Gütersloh : Luchterhand.

Wolf, C. 1996. Medea. Gütersloh : Luchterhand. 